\title{
Intrahost evolution of the HIV-2 capsid correlates with progression
}

\section{to AIDS}

M. T. Boswell (1) *, J. Nazziwa (2), K. Kuroki (3), A. Palm (2), S. Karlson (2), F. Månsson (2), A. Biague (4), Z. J. da Silva (4), C.O. Onyango (5), T.I. de Silva (6, 7), A. Jaye (7), H. Norrgren (8), P. Medstrand (2), M. Jansson (9), K. Maenaka (3), S. L. Rowland-Jones (1,7), J. Esbjörnsson $(1,2){ }^{*}$, and the SWEGUB CORE group

1. Nuffield Department of Medicine, University of Oxford, United Kingdom. 2. Department of Translational Medicine, Lund, Lund University, Sweden. 3. Faculty of Pharmaceutical Sciences and Global Station for Biosurfaces and Drug Discovery, Hokkaido University, Japan. 4. National Public Health Laboratory, Bissau, Guinea-Bissau. 5. US Centres for Disease Control, Kenya. 6. Department of Infection, Immunity and Cardiovascular Disease, The Medical School, University of Sheffield, United Kingdom. 7. Medical Research Council Unit The Gambia at the London School of Hygiene and Tropical Medicine, Fajara, The Gambia. 8. Department of Clinical Sciences Lund, Lund University, Sweden. 9. Department of Laboratory Medicine, Lund, Lund University, Sweden

*Corresponding Authors:

Michael T. Boswell

Nuffield Department of Medicine, University of Oxford, United Kingdom

Postal address: NDM Research Building. University of Oxford. Old Road Campus.

Roosevelt Drive. Oxford. OX3 7FZ.

Email: boswell.michaelt@gmail.com

Joakim Esbjörnsson

Department of Translational Medicine, Lund, Lund University, Sweden

Postal address: Systems Virology, BMC B13, 22184 Lund, Sweden

Email: joakim.esbjornsson@med.lu.se

Short title: HIV-2 capsid intrahost evolution

Keywords: HIV-2; evolution; disease progression; phylogenetics; capsid; p26 
medRxiv preprint doi: https://doi.org/10.1101/2021.12.28.21268379; this version posted January 7, 2022. The copyright holder for this preprint (which was not certified by peer review) is the author/funder, who has granted medRxiv a license to display the preprint in It is made available under a CC-BY-ND 4.0 International license .

\section{Abstract}

Background: HIV-2 infection will progress to AIDS in most patients without treatment, albeit at approximately half the rate of HIV-1 infection. HIV-2 p26 amino acid variations are associated with lower viral loads and enhanced processing of $T$ cell epitopes, which may lead to protective Gag-specific CTL responses common in slower disease progressors. Lower virus evolutionary rates, and positive selection on conserved residues in HIV-2 env have been associated with slower progression to AIDS. We therefore aimed to determine if intrahost evolution of HIV-2 p26 is associated with disease progression.

Methods: Twelve treatment-naïve, HIV-2 mono-infected participants from the GuineaBissau Police cohort with longitudinal CD4+ T cell data and clinical follow-up were included in the analysis. CD4\% change over time was analysed via linear regression models to stratify participants into relative faster and slower disease progressor groups. Gag amplicons of 735 nucleotides which spanned the p26 region were amplified by PCR and sequenced. We analysed p26 sequence diversity evolution, measured site-specific selection pressures and evolutionary rates, and determined if these evolutionary parameters were associated with progression status. Amino acid polymorphisms were mapped to existing p26 protein structures.

Results: In total, 369 heterochronous HIV-2 p26 sequences from 12 male patients with a median age of 30 (IQR: 28-37) years at enrolment were analysed. Faster progressors had lower $\mathrm{CD} 4 \%$ and faster CD4\% decline rates. Median pairwise sequence diversity was higher in faster progressors $\left(5.7 \times 10^{-3}\right.$ versus $1.4 \times 10^{-3}$ base substitutions per site, $P<0.001)$. p26 evolved under negative selection in both groups $(\mathrm{dN} / \mathrm{dS}=0.12)$. Virus evolutionary rates were higher in faster than slower progressors - synonymous rates: $4.6 \times 10^{-3}$ vs. $2.3 \times 10^{-3}$; and nonsynonymous rates: $6.9 \times 10^{-4}$ vs. $2.7 \times 10^{-4}$ substitutions/site/year, respectively. Virus evolutionary rates correlated negatively with CD4\% change rates $(\rho=-0.8, P=0.02$ ), but not CD4\% level. However, Bayes factor (BF) testing indicated that the association between evolutionary rates and $C D 4 \%$ kinetics was supported by weak evidence $(B F=0.5)$. The signature amino acid at p26 positions 6,12 and 119 differed between faster $(6 \mathrm{~A}, 12 \mathrm{l}, 119 \mathrm{~A})$ and slower (6G, 12V, 119P) progressors. These amino acid positions clustered near to the TRIM5a/p26 hexamer interface surface.

Conclusions: Faster $p 26$ evolutionary rates were associated with faster progression to AIDS and were mostly driven by synonymous substitutions. Nonsynonymous evolutionary rates were an order of magnitude lower than synonymous rates, with limited amino acid sequence evolution over time within hosts. These results indicate the HIV-2 p26 may be an attractive vaccine or therapeutic target. 
medRxiv preprint doi: https://doi.org/10.1101/2021.12.28.21268379; this version posted January 7, 2022. The copyright holder for this preprint (which was not certified by peer review) is the author/funder, who has granted medRxiv a license to display the preprint in It is made available under a CC-BY-ND 4.0 International license .

\section{Introduction}

81 HIV-1 and HIV-2 are retroviruses which transmitted from non-human primates to humans in the 20th century. HIV-1 has four main groups, of which $\mathrm{M}$ accounts for $98 \%$ of global infections. HIV-1 group M descended from SIVcpz which circulates in chimpanzees (1). HIV-2 is descended from SIVsm which circulates in sooty mangabeys, and has nine groups $(A-I)$, of which $A$ and $B$ account almost all human infections (1). HIV-1 has caused a global pandemic, whereas HIV-2 has remained an endemic infectious disease in West Africa, with limited spread outside the region (2). In addition to stark differences in transmissibility, the two viruses differ in disease progression rates $(3,4)$. In the absence of treatment, HIV-1 will progress to AIDS twice as fast as HIV-2. However, HIV-2 disease progression is highly variable, with some patients developing AIDS in similar timeframes as HIV-1 and other progressing far more slowly.

After infecting a host, these viruses rapidly diversify and circumvent host immune responses, founding numerous sub-populations known as the virus quasispecies (5). An extensive body of literature has connected intrahost evolution of HIV-1 to disease progression and phenotypic trait development (6-12). Synonymous evolutionary rates (nucleotide substitutions which do not change amino acid sequences) in HIV-1 env correlate with time to AIDS, CD4+ count decline rates and viral load, while

100 nonsynonymous evolutionary rates are not associated with disease progression.

101 Similar associations have been reported for intrahost evolution HIV-1 gag (13). In HIV-

1021 infection, higher replicative capacity of founder viruses explains much of the variation 103 in disease progression rates, and is strongly associated with increasing $\mathrm{T}$ cell activation and exhaustion (14). Together these results suggest that faster virus 
medRxiv preprint doi: https://doi.org/10.1101/2021.12.28.21268379; this version posted January 7, 2022. The copyright holder for this preprint (which was not certified by peer review) is the author/funder, who has granted medRxiv a license to display the preprint in perpetuity.
It is made available under a CC-BY-ND 4.0 International license.

replication drives HIV-1 disease progression due to heightened immune activation, rather than evolution being driven by immune escape (11).

HIV-2 env evolutionary rates in faster disease progressors are approximately double that of slower progressors (15). In HIV-2 infection the relationship between immune activation and progressive CD4+ T cell loss is similar to that in HIV-1, at equivalent degrees of immune suppression (16). This suggests that evolutionary rates, immune activation, and subsequent disease progression are similarly linked in HIV-1 and HIV2 infection.

The HIV-1 capsid is a fullerene cone structure made up of 216 p24 hexamers, and 12 p24 pentamers (17). The capsid is critical in the viral replication cycle, with several indispensable functions including nucleotide supply to the replicating virus, nuclear import to facilitate integration, cyclophilin-A (CyPA) binding, and immune evasion (1821). HIV-1 and HIV-2 capsids bind to the innate sensor NONO in the nucleus, which triggers the cGAS-STING pathway to activate innate immune responses in macrophages and dendritic cells (21). HIV-2 binds NONO with higher affinity than HIV1. HIV-2 capsids are also more sensitive to restriction factor TRIM5a than HIV-1 (22). Polymorphisms in HIV-2 p26 have been linked to disease progression. Specifically, participants with low viral loads often have prolines in p26 positions 119, 159 and 178 (23). Prolines at position 159 and 178 are associated with enhanced proteasomal processing of CD8 ${ }^{+} \mathrm{T}$ cell epitopes and greater Gag-specific $\mathrm{T}$ cell responses, and is a frequent target for T cell responses which are associated with low viral loads (24). Additionally, proline at position 119 in p26 alters the conformation of the capsid structure and is associated with increased sensitivity to TRIM5a $(25,26)$. 
medRxiv preprint doi: https://doi.org/10.1101/2021.12.28.21268379; this version posted January 7, 2022. The copyright holder for this preprint (which was not certified by peer review) is the author/funder, who has granted medRxiv a license to display the preprint in It is made available under a CC-BY-ND 4.0 International license.

130 We tested this hypothesis by analysing the following in relation to HIV-2 disease

131 progression: i) pairwise sequence diversity evolution; ii) site-specific selection

132 pressures; iii) synonymous and nonsynonymous evolutionary rates in p26 and iv) p26

133 amino acid sequence variation in the virus quasispecies.

\section{Methods}

136 This section provides a summary of the main laboratory and statistical methods used

137 in this study. Further details are available in the supplementary materials.

\section{Study participants}

140 Study participants were recruited to the Guinea-Bissau Police cohort between 1990-

141 2009. Informed consent was obtained from the participants and the study was

142 approved by the research ethic committees of the Ministry of Health in Guinea-Bissau,

143 Lund University and the Karolinska Institute, Sweden. Twelve HIV-2 infected

144 participants were included in this analysis based on availability of plasma samples.

145 Selection criteria included that the participants were: HIV-2 monoinfected, 146 antiretroviral therapy (ART) naïve at the time of plasma sample collection and had

147 longitudinal CD4+ T cell measurements available which allowed for estimation of

148 disease progression (Table S1). Clinical and immunological staging of HIV disease

149 was done according to the WHO criteria (27). A total of seven participants had an

150 estimated date of HIV-2 seroconversion (seroincident) and five participants were

151 HIV-2 positive at enrolment (seroprevalent). T cell data was analysed from the first

152 time point after HIV-2 detection, in seroincident participants this time point was the first

153 one after their documented seroconversion, and in seroprevalent participants at

154 enrolment into the cohort. 
medRxiv preprint doi: https://doi.org/10.1101/2021.12.28.21268379; this version posted January 7, 2022. The copyright holder for this preprint (which was not certified by peer review) is the author/funder, who has granted medRxiv a license to display the preprint in It is made available under a CC-BY-ND 4.0 International license .

\section{Analysis of disease progression markers in HIV-2}

156 Both absolute CD4+ T cell counts and CD4+ T cell percentage (CD4\%) are reliable

157 immunological markers of HIV disease progression. In resource-limited settings, CD4+

158 T cell percentages (CD4\%) are less sensitive to specimen handling, patient age, or

159 time of sampling when compared to absolute CD4 counts (28-31). We therefore chose

160 to analyse disease progression using CD4\% change over time. Briefly, participants'

161 longitudinal CD4\% were analysed in per-participant linear regression models. The

162 CD4\% level at the midpoint in follow-up time after HIV-2 detection and the CD4\%

163 change rate (slope of the regression line) were extracted from these models and

164 analysed as markers of disease progression.

165

166 To create disease progression groups, participants were ranked and classified

167 according to three approaches as previously described (15) i) from highest midpoint

168 CD4\% to the lowest (those above the mean were classified as slower progressors and

169 those below the mean as faster progressors); ii) from highest positive change rate to

170 the lowest negative change rate; iii) the midpoint CD4\%, and CD4\% change rate were

171 then transformed into proportional values, added together, and averaged for each

172 participant. This gave a combined coefficient for each participant which was weighted

173 equally according to midpoint CD4\% and the rate of change which accounts for

174 differences in disease stage at enrolment. The combined coefficient was used to rank

175 participants and stratify them into relative progression with distinct disease phenotypes

176 - faster and slower disease progression (Table S2). All analyses which refer to

177 progression groups used this combined coefficient for stratification. 
medRxiv preprint doi: https://doi.org/10.1101/2021.12.28.21268379; this version posted January 7, 2022. The copyright holder for this preprint (which was not certified by peer review) is the author/funder, who has granted medRxiv a license to display the preprint in It is made available under a CC-BY-ND 4.0 International license.

\section{RNA extraction and PCR amplification}

180 Briefly - plasma samples had previously been collected from participants and stored

181 at $-80^{\circ} \mathrm{C}$; we extracted RNA using the RNeasy Lipid Tissue Mini Kit (Qiagen, Venlo,

182 Netherlands) with minor modifications to the manufacturer's instructions. Following

183 RNA extraction, a nested PCR was performed with $5 \mu \mathrm{L}$ of extracted RNA. The first step involved a one-step reverse transcription PCR (RT-PCR) using the SuperScript IV One-Step RT-PCR System with Platinum Taq DNA Polymerase (supplementary materials [Tables S3-6]). Immediately following the RT-PCR a second nested reaction using an inner set of HIV-2 p26 primers was performed using the Dream Taq PCR kit

188 (Thermo Fisher Scientific, Waltham, MA (Figure S1). Primer sequences are listed in 189 Table S4.

\section{Cloning and sequencing}

Amplicons of 846 nucleotides from position 1411-2257 on HIV-2 BEN.M30502 were

193 cloned into pCR $^{\circledR} 4$ TOPO $^{\circledR}$ vector using TOPO-TA cloning kit (Invitrogen, Carlsbad,

194 CA, USA); 23 white colonies were randomly picked and amplified by colony-PCR using the Advantage 2 PCR kit (Takara, Kusatsu, Japan) (Figure S2), to confirm presence of the insert. The plasmids containing inserts were sequenced by Sanger sequencing

197 using the inner PCR primers (Table S4) (Macrogen Europe, Amsterdam, 198 Netherlands).

\section{Sequence analysis}

201 Raw sequence data were analysed in Geneious Prime v. 2019.2 (Geneious,

202 Biomatters, Auckland, New Zealand), mapped to the HIV-2 BEN.M30502 reference 203 sequence and trimmed for quality (32). Contigs were constructed for each participant 
medRxiv preprint doi: https://doi.org/10.1101/2021.12.28.21268379; this version posted January 7, 2022. The copyright holder for this preprint (which was not certified by peer review) is the author/funder, who has granted medRxiv a license to display the preprint in It is made available under a CC-BY-ND 4.0 International license.

204 from single forward and reverse reads. Poor quality reads and contigs with high quality

205 (HQ) scores of less than $80 \%$ were not included in further downstream analysis. This score indicates that $80 \%$ of bases are high quality and that the likelihood of a false positive base reading is 1:10 000 (33). Mixed peaks in electropherograms were resolved in favour of the consensus nucleotide at the base. Contigs were assembled into participant-specific alignments and mapped to HIV-2 BEN.M30502 to ensure that all participant sequences mapped to the same coding region of gag. Recombination

211 between sequences grouped in an alignment can violate the assumptions made in

212 phylogenetic analysis $(34,35)$. We therefore screened each participant-specific

213 dataset for recombination in RDP4 using a combination of the following methods:

214 RDP, GENECONV, BootScan, MaxChi and Chimaera (35-40). All sequences showing evidence of recombination were removed from further analysis.

\section{Bayesian phylogenetic analysis}

218 All Bayesian phylogenetic parameters were specified in BEAUti v. 1.10.4 and run in

219 BEAST v1.10.4 with parallel processing by BEAGLE $(41,42)$. Model output logs were analysed in Tracer v1.7 (43) and assessed for convergence by visual inspection of the posterior distribution chains and if effective sample sizes (ESSs) were $>100$, after $10 \%$ burn-in. All analyses were run in duplicate to assess reproducible convergence. Bayesian phylogenetic models were used to (i) perform viral subtyping (ii) reconstruct the most recent common ancestor (MRCA) for the participants' combined sequence alignment, (iii) measure pairwise sequence diversity within patient sequence alignments (iv) estimate site-specific dN/dS ratios in p26 for each participant (v) estimate relaxed molecular clock estimates for individual participants and (vi) estimate participant-specific molecular clock rates via a hierarchical phylogenetic model (HPM) 
medRxiv preprint doi: https://doi.org/10.1101/2021.12.28.21268379; this version posted January 7, 2022. The copyright holder for this preprint (which was not certified by peer review) is the author/funder, who has granted medRxiv a license to display the preprint in It is made available under a CC-BY-ND 4.0 International license .

229 i) Viral subtyping was done by sampling HIV-2 gag sequences from the clonal 230 sequences. Gag sequences for HIV-2 groups A - G as well as SIVsmm and HIV-1

231 were downloaded from the Los Alamos National Laboratory (LANL) sequence 232 database, and an alignment of the participant HIV-2 sequences with these reference 233 sequences was created (Table S7). Viral subtyping was performed using a Bayesian 234 phylogenetic approach. A strict molecular clock model, HKY substitution model and constant population size were specified. The Markov chain was run for $2 \times 10^{6}$ 236 iterations.

237 ii) The following parameters were used for the MRCA reconstruction - strict molecular 238 clock model, GTR nucleotide substitution model, no site heterogeneity or codon 239 partition, constant population size. The Markov chain was run for $2.5 \times 10^{6}$ iterations.

240 The MRCA was used as a reference sequence for variant identification and mapping 241 of amino acid variants over time (discussed below).

iii) To measure pairwise sequence diversity the sequences from the patient samples are labelled according to the time point of collection, these are then aligned using

244 CLUSTAL-W. Using GARLI V2.01, 200 maximum likelihood bootstrap trees are generated for each dataset. The diversity estimates in base substitution per base site are obtained from each of the 200 trees using the BIOTREE:IO function of the BioPerl package. These estimates are then summarised in $\mathrm{R}$ to get the mean diversity and the 95\% confidence intervals.

iv) To estimate selection pressure the $\mathrm{dN} / \mathrm{dS}$ ratio is calculated by dividing the

250 nonsynonymous evolutionary $(\mathrm{dN})$ rate by the synonymous (dS) evolutionary rate (a 251 ratio of less than 1.0 will indicate negative selection; a ratio equal to 1.0 neutral selection, and a ratio greater than 1.0 positive selection at a site). We measured site- 
medRxiv preprint doi: https://doi.org/10.1101/2021.12.28.21268379; this version posted January 7, 2022. The copyright holder for this preprint (which was not certified by peer review) is the author/funder, who has granted medRxiv a license to display the preprint in

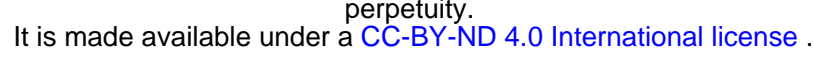

specific selection pressures using Renaissance counting procedures performed with the following model parameters - a strict molecular clock model, GTR nucleotide substitution model, no site heterogeneity, a 1,2,3 codon partition, constant population size and $4 \times 10^{7}$ MCMC chains (44).

v) To determine combined, synonymous and nonsynonymous evolutionary rates derived from the participant-specific relaxed molecular clock models we used software packages developed by Lemey et al. (11). Briefly, for each participant nucleotide alignment a relaxed molecular clock model was created in BEUti and run in BEAST. Model parameters included an HKY nucleotide substitution model, gamma site heterogeneity, a constant population size and $2 \times 10^{8}$ MCMC chains. For each participant 10000 trees were simulated as a posterior sample distribution. From these 10000 trees 200 were selected randomly after a 10\% burn-in and separated into nucleotide substitution unit denoted and time unit denoted trees. The substitution trees were then separated further using HyPhy into expected synonymous and nonsynonymous substitution trees. Next, these substitution trees were analysed separately in conjunction with their respective time unit trees to generate estimates of the combined, synonymous, and nonsynonymous evolutionary rates. Lastly, the substitution trees were used to estimate divergence as a function of time from the first time point to the last time point in the alignment. This allowed us to plot divergence over time.

vi) A significant limitation of the relaxed molecular clock estimates described above are interparticipant variability in number of sequences, number of time points, and total follow-up time. The HPM allows for feedback across participant average estimates to improve participant specific estimates, thereby making use of a larger data set (all sequences linked in the HPM) to inform smaller partitions in the data (participant 
medRxiv preprint doi: https://doi.org/10.1101/2021.12.28.21268379; this version posted January 7, 2022. The copyright holder for this

preprint (which was not certified by peer review) is the author/funder, who has granted medRxiv a license to display the preprint in It is made available under a CC-BY-ND 4.0 International license.

specific estimates). Another main difference in the HPM estimates versus those above are that HPMs assume a strict molecular clock per partition which does not vary for each taxon while the previous estimates assumed an uncorrelated relaxed molecular clock per participant. We partitioned the HPM by using fixed factor terms for the combined coefficient stratification, as well as the log values of the midpoint CD4\% and CD4\% change rate. Model parameters included a strict molecular clock model, HKY nucleotide substitution model, gamma site heterogeneity, a 1,2 and 3 codon partition, constant population size. The Markov chain was run for $6 \times 10^{8}$ iterations. We calculated Bayes Factors to test whether the midpoint CD4\% and CD4\% change rate were significant explanatory variables in evolutionary rate estimates. We repeated the HPM analysis with a narrower range of prior values which could be assessed by the model. Our initial HPM used a hyperprior scale parameter of 1000 , and we subsequently adjusted these to scales of 100 and 10 - this allows for a narrower distribution of values to be assessed for prior parameters (45).

\section{Amino acid sequence analysis}

We translated and aligned all p26 sequences to the MRCA to identify single amino acid polymorphisms (SAAPs). We categorised SAAPs as majority variants if they occurred in more than $50 \%$ of sequences; and minority variants if the prevalence was below $50 \%$. Polymorphisms found in a single sequence were designated as private variants. Private single nucleotide polymorphisms identified in virus quasispecies using cloning and Sanger sequencing are often not found using next-generation sequencing platforms and may represent a combination of PCR and sequencing errors (46). 
medRxiv preprint doi: https://doi.org/10.1101/2021.12.28.21268379; this version posted January 7, 2022. The copyright holder for this preprint (which was not certified by peer review) is the author/funder, who has granted medRxiv a license to display the preprint in It is made available under a CC-BY-ND 4.0 International license .

303 To test whether the frequency of variants significantly differed between progression

304 groups, we divided the sequence alignment by progression status (faster vs. slower

305 progressors). We then created new alignments of 1000 sequences per progression

306 group (randomly selected via bootstrap sampling with replacement). We then

307 compared the amino acid frequencies by progressor group using the Viral

308 Epidemiology Signature Pattern Analysis (VESPA) tool (47). VESPA identifies

309 signature patterns, which differ between alignments and reports frequencies of the

310 specific amino acids in each alignment. HIV-2 p26 structural models were generated

311 in Pymol v. 1.8, using protein sequence PDB ID: 2WLV (48). Residues which have

312 been linked to important functional regions/structures on the HIV-1 p24 protein were

313 used to infer sites on HIV-2 p26 which may have a similar role. This was done by

314 aligning reference sequences HIV-1.NL4-3 and HIV-2 BEN.M30502.

316 Caio cohort sequence analysis

317 We investigated whether the signature amino acid variants identified by the VESPA

318 analysis were associated with disease progression markers in a larger, external

319 cohort. This was done by testing the association of these p26 amino acid variants with

320 CD4\% and HIV-2 plasma viral loads in 86 HIV-2 positive participants from the Caio

321 cohort $(23,49)$.

323 Statistical analysis

324 All statistical analyses were 2-sided, and data visualisations were done in R studio v.

325 4.0.3, unless specified otherwise $(50,51)$. Baseline characteristics of participants were

326 summarised as means and standard deviations, medians, and interquartile ranges,

327 and counts with percentages. Pairwise testing was performed using the Mann Whitney 
medRxiv preprint doi: https://doi.org/10.1101/2021.12.28.21268379; this version posted January 7, 2022. The copyright holder for this preprint (which was not certified by peer review) is the author/funder, who has granted medRxiv a license to display the preprint in It is made available under a CC-BY-ND 4.0 International license.

U (MW) test for non-normally distributed data, and the Student's T test for normally distributed data. To compare distributions of repeated measurements between the progression groups we used Friedman tests with effect sizes reported by Kendall's W value (small effect: $W=0.1-0.3$; moderate effect: $0.3-0.5$ and large effect $>0.5$ ). The frequency of categorical variables was assessed by chi squared tests. Proportional differences were also assessed using the Fisher's Exact Test (FET) and reported as odds ratios (ORs). Correlation statistics were calculated using the Pearson (parametric) or Spearman's (non-parametric) correlation coefficients dependent on the variables' distribution. Pairwise sequence diversity evolution was quantified using linear mixed effects models with model fit assessed by the likelihood ratio test (LRT). A False discovery rate (FDR) was used to correct for multiple comparisons. Statistical significance was determined as $P<0.05$.

\section{Results}

342 Our analysis included 12 HIV-2 infected participants from the Guinea-Bissau Police cohort. All participants were male with a median age at enrolment of 30 (IQR: 28-37) years. The cohort median midpoint CD4\% was $27.5 \%$, and the median CD4\% change rate was $-0.05 \%$ per year. After calculation of the combined coefficient and assignment to progression groups there were six faster progressors and six slower progressors.

347 Faster progressors had a significantly lower midpoint CD4\% than slower progressors (20.7\% vs. $30.6 \%, P=0.02, \mathrm{MW})$. In addition, the faster progressors' CD4\% decreased by $1.4 \%$ per year, whereas the slower progressors' CD4\% increased by $0.6 \%$ per year

$350(P=0.02, \mathrm{MW}))$. One of the slower progressors developed severe immunosuppression

351 (CD4\% below 15), whereas 5/6 faster progressors reached a CD4\% below $15 \%$ during 
medRxiv preprint doi: https://doi.org/10.1101/2021.12.28.21268379; this version posted January 7, 2022. The copyright holder for this

preprint (which was not certified by peer review) is the author/funder, who has granted medRxiv a license to display the preprint in It is made available under a CC-BY-ND 4.0 International license .

353 to the first sample was 4.5 (IQR: 3.9-6.7) years, and in seroprevalent participants the

354 median time from HIV-2 detection (enrolment) to sample was 14.4 (IQR: 2.4-15.6)

355 years. The mean follow-up time from first to last sequencing sample was 5.9 years,

$356 \quad 6.1$ years for faster progressors and 5.7 for slower progressors.

357

358 After aligning the sequences and trimming for quality, the analysed gag sequences spanned 735 nucleotides in a single open reading frame which mapped to nucleotide 1460-2194 on HIV-2 BEN.M30502. These sequences are available from Genbank with accession numbers OL872372-872739 and OM146012. This sequence included the

362 first 687 nucleotides, from 5' to 3', of the p26 region of gag. Twenty-five plasma 363 samples yielded PCR products from the 12 participants; with PCR products from 364 longitudinal sample time points generated from nine participants (Table 1). In total 575 clones were generated and sequenced, whereof 173 were removed due to poor sequence quality or presence of stop codons. Of the remaining 402 sequences, 33 were possible recombinant sequences, and were removed from further analysis. This

368 resulted in a final dataset of 369 sequences from 12 study participants (median: 30 sequences/participant; Figure 1). Participant sequences formed monophyletic clusters with high posterior support values, suggesting that contamination or labelling errors did not occur during sample handling. No clear clustering pattern by progression

372 status was observed (Figure S3). Moreover, the subtype analysis indicated that all 373 sequences clustered with HIV-2 group A reference sequences (Table S7) (Figure S4). 
medRxiv preprint doi: https://doi.org/10.1101/2021.12.28.21268379; this version posted January 7, 2022. The copyright holder for this preprint (which was not certified by peer review) is the author/funder, who has granted medRxiv a license to display the preprint in It is made available under a CC-BY-ND 4.0 International license.

Table 1: Summary results for the study participants.

\begin{tabular}{|c|c|c|c|c|}
\hline Study ID & HIV-2 serostatus ${ }^{1}$ & Midpoint CD4\% ${ }^{2}$ & CD4\% change rate ${ }^{3}$ & Progression ${ }^{4}$ \\
\hline DL2051 & Prevalent & 30.7 & -1.8 & Faster \\
\hline DL2386 $^{5}$ & Incident & 25.3 & -1.6 & Faster \\
\hline DL2524 & Prevalent & 32.7 & 0.7 & Slower \\
\hline DL2533 & Prevalent & 25.1 & 1.1 & Slower \\
\hline DL3248 & Incident & 29.4 & 1 & Slower \\
\hline DL3286 & Incident & 32.7 & -0.1 & Slower \\
\hline DL3405 & Incident & 33.1 & 1.5 & Slower \\
\hline DL3542 & Prevalent & 30.8 & -1 & Slower \\
\hline DL3646 & Prevalent & 18.2 & -0.3 & Faster \\
\hline DL3740 & Incident & 16.5 & 0.7 & Faster \\
\hline DL3761 & Incident & 16 & -3.7 & Faster \\
\hline DL3941 & Incident & 17.4 & -1.9 & Faster \\
\hline
\end{tabular}

${ }^{1}$ HIV-2 serostatus includes seroincident (where an estimated date of seroconversion is available), and seroprevalent participants (where a participant was HIV-2 positive at time of enrolment). ${ }^{2}$ Midpoint CD4\% calculated from per-patient regression models. ${ }^{3} \mathrm{CD} 4 \%$ change rate per year is the linear regression coefficient of CD $4 \%$ over time. ${ }^{4}$ Progression status as determined by the combined coefficient ${ }^{5}$ Sample I for participant DL2386 did not have a time stamp. We therefore used the midpoint in follow-up time for this participant with an uncertainty correction of \pm 9 years in all phylogenetic models which required a date for the sample.

\section{Pairwise sequence diversity is associated with disease progression status}

385 Sequence diversity increased over time (Spearman correlation: $\rho=0.26, P<0.001$,

386 Figure 1). The pooled median sequence diversity was significantly higher among

387 faster than slower progressors $\left(5.7 \times 10^{-3}\right.$ versus $1.4 \times 10^{-3}$ base substitutions per site, MW $P<0.001)$. Analysing linear regression models of diversity over time, the average sequence diversity increased

390 substitutions per site, per year (s/s/y), for the fasters progressors, and increased by

$3911.3 \times 10^{-4} \mathrm{~s} / \mathrm{s} / \mathrm{y}\left(95 \% \mathrm{Cl}: 1.1-1.4 \times 10^{-4}, P<0.001\right)$ for the slower progressors. To account

392 for the unequal contribution of sequences, time points, and inter-participant variability,

393 we analysed mixed effects models. A random slope and intercept model (time (i.e.,

394 slope of diversity) allowed to vary by participant (random effect)) provided the best

395 model fit $(P<0.001$, LRT $)$. In this model, progression status was not associated with a 


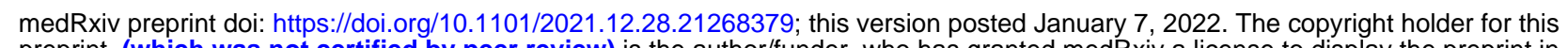
preprint (which was not certified by peer review) is the author/funder, who has granted medRxiv a license to display the preprint in It is made available under a CC-BY-ND 4.0 International license .

396

397

398

significant effect on diversity change over time (faster progression diversity increased

by $1.2 \times 10^{-3}$ relative to slower progression, $\left.95 \% \mathrm{Cl}=-9.2 \times 10^{-4}-3.5 \times 10^{-3}, P=0.2\right)$.

Time point $\square$ I $\square \mathrm{II} \square \mathrm{II}$
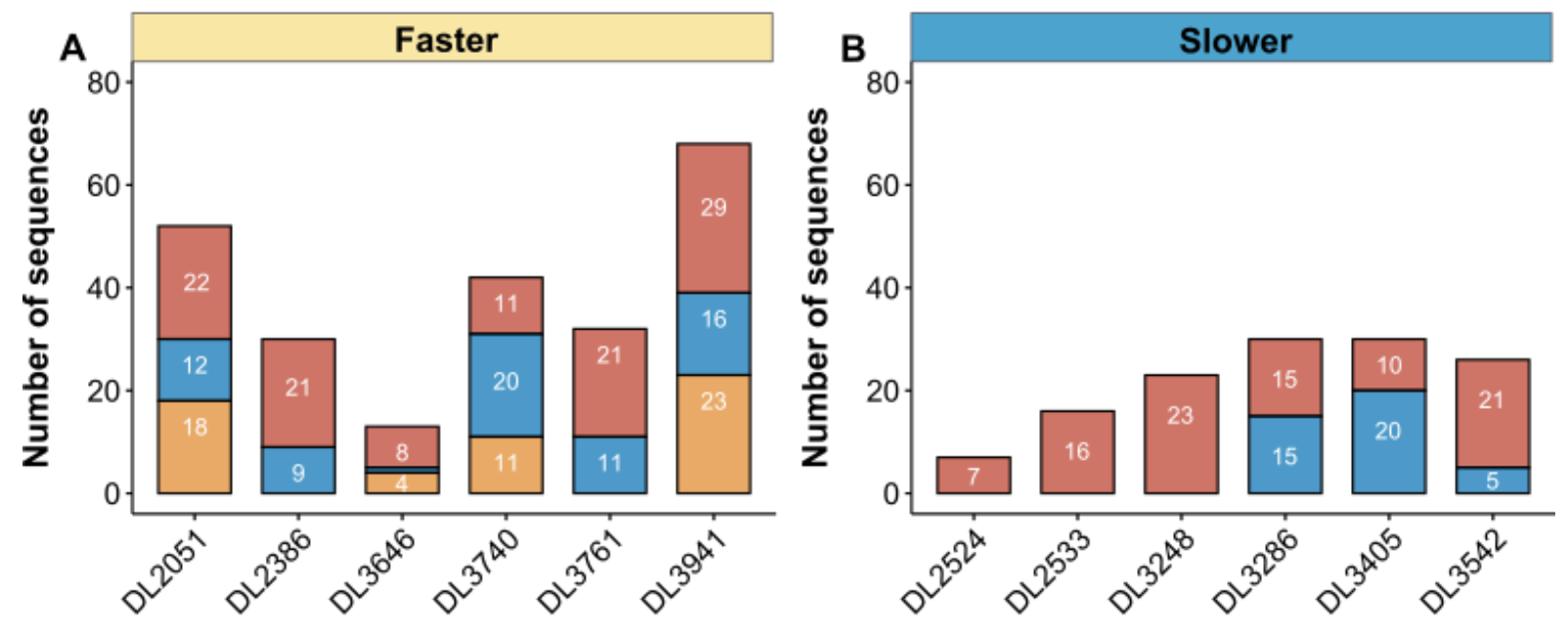

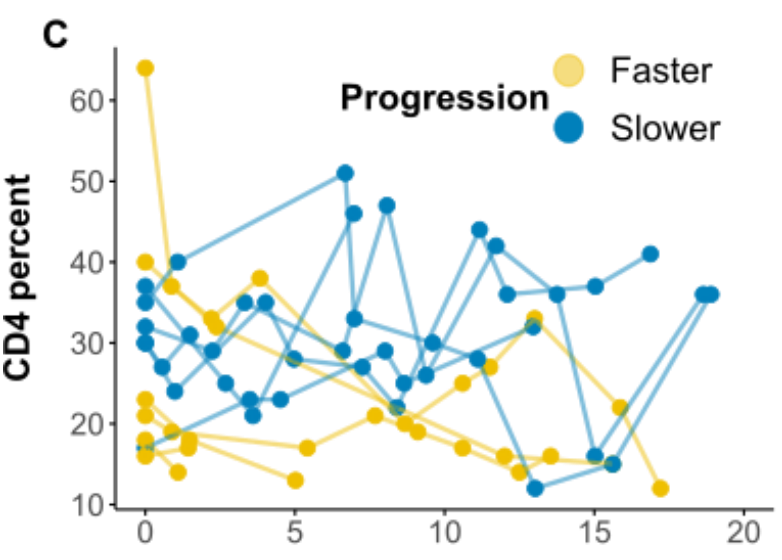

Years from HIV-2 detection

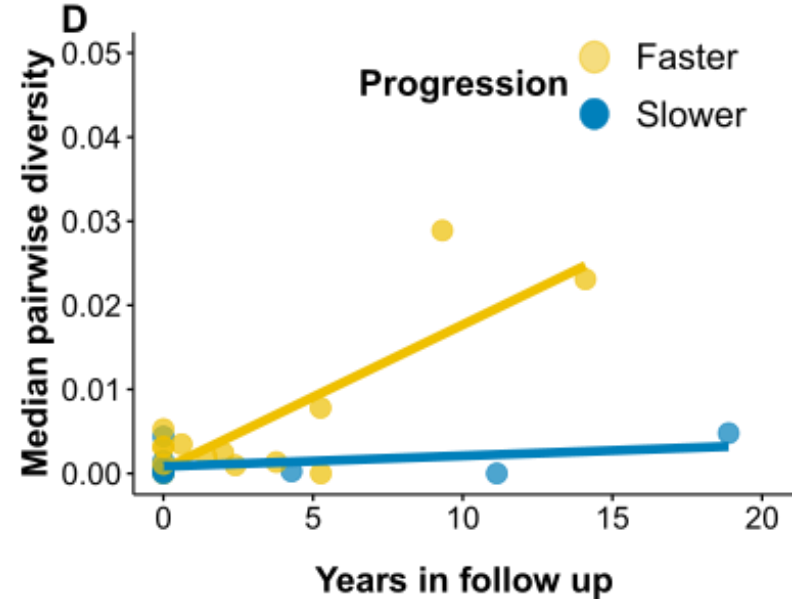

400 Figure 1. Summary of number of sequences, CD4\% kinetics, and pairwise diversity by

401 progression status. A - B) Bar plots summarise the number of sequences per patient and 402 time point. Panels are stratified by progression status as determined by the combined 403 coefficient. There are six faster and slower progressors. Slower progressors had fewer 404 sequences (numbers inside the bars) and time points for analysis than faster progressors. C) 405 CD4\% kinetics shown for faster and slower progressors as defined by the combined 406 coefficient. Faster progressors had a significantly lower CD4\% and faster CD4\% decline rates 407 than slower progressors $(P<0.05, M W)$. D) Scatter plots with fitted linear regression lines 408 showing pairwise diversity increasing over time, presented as nucleotide substitutions per site 409 ( $y$-axis) and time in years between samples ( $x$-axis). Pairwise sequence diversity was higher 410 than slower progressors $(P<0.05, \mathrm{MW})$. 
medRxiv preprint doi: https://doi.org/10.1101/2021.12.28.21268379; this version posted January 7, 2022. The copyright holder for this preprint (which was not certified by peer review) is the author/funder, who has granted medRxiv a license to display the preprint in It is made available under a CC-BY-ND 4.0 International license.

412 Progression status is associated with synonymous and nonsynonymous

413 evolutionary rates

414 The results for the relaxed clock estimates are reported for nine participants (six faster

415 and three slower) who had sequences from multiple time points available. The median

416 evolutionary rate in p26 for all participants was $4.0 \times 10^{-3}$ (IQR: $\left.2.6-6.9 \times 10^{-3}\right) \mathrm{s} / \mathrm{s} / \mathrm{y}$.

417 Evolutionary rates correlated negatively with CD4\% change rates, but not midpoint

418 CD4\% (Spearman correlation: $\rho=-0.8$ and -0.5 respectively, $P=0.02$ and 0.17 ). Faster

419 progressors had a significantly higher evolutionary rate than slower progressors

$420\left(5.4 \times 10^{-3}\right.$ vs. $2.5 \times 10^{-3} \mathrm{~s} / \mathrm{s} / \mathrm{y}, \mathrm{W}=0.4$, FT $P<0.001$, Figure 2$)$. The median synonymous

421 evolutionary rate for all participants was $3.5 \times 10^{-3}$ (IQR: $2.3-6.1 \times 10^{-3}$ ) s/s/y and was

422 also significantly higher in faster than slower progressors $\left(4.6 \times 10^{-3} \mathrm{vs} .2 .3 \times 10^{-3} \mathrm{~s} / \mathrm{s} / \mathrm{y}\right.$,

$423 \mathrm{~W}=0.4, \mathrm{FT} P<0.001$, Figure 2). The median nonsynonymous evolutionary rate for all

424 participants was $4.1 \times 10^{-4}\left(\mathrm{IQR}: 2.4-8.8 \times 10^{-4}\right) \mathrm{s} / \mathrm{s} / \mathrm{y}$ and was significantly higher in

425 faster than slower progressors $\left(6.9 \times 10^{-4}\right.$ vs. $2.7 \times 10^{-4} \mathrm{~s} / \mathrm{s} / \mathrm{y}, \mathrm{W}=0.4, \mathrm{FT} P<0.001$,

426 Figure 2). The $d N / d S$ ratio for p26 in was 0.12 (IQR: 0.08-0.21), and the difference

427 between faster and slower progressors was small but significant $(0.13$ vs. $0.11, \mathrm{~W}=$

$428 \quad 0.2$, FT $P<0.001)$. Relaxed evolutionary rate estimates are summarised for each

429 participant in the supplementary materials (Table S8). The effect sizes for progression

430 groups on evolutionary rate comparisons were moderate $(\mathrm{W}=0.4)$, and for $\mathrm{dN} / \mathrm{dS}$

431 ratios small $(\mathrm{W}=0.2)$. Synonymous and nonsynonymous divergence in $p 26$ increased

432 linearly with time in both faster and slower progressors (Figure 2). Linear regression

433 models were fitted to each participant's divergence over time ( $r^{2}$ for synonymous and

434 nonsynonymous divergence was 0.94 and 0.82 , respectively). 
medRxiv preprint doi: https://doi.org/10.1101/2021.12.28.21268379; this version posted January 7, 2022. The copyright holder for this preprint (which was not certified by peer review) is the author/funder, who has granted medRxiv a license to display the preprint in It is made available under a CC-BY-ND 4.0 International license .

436 We next analysed a series of HPMs to generate estimates of evolutionary rates in p26

437 for each participant with multiple time points and tested the correlation between 438 evolutionary rates, midpoint CD4\% and CD4\% change rate. The median HPM 439 evolutionary rate for all participants was $3.1 \times 10^{-3} \mathrm{~s} / \mathrm{s} / \mathrm{y}\left(95 \%\right.$ HPD: $\left.1.9-4.5 \times 10^{-3}\right)$ and 440 correlated well with the relaxed clock estimates (Spearman correlation: $\rho=0.8$, $441 P=0.008)$. We analysed the midpoint CD4\%, CD4\% change rates and the combined 442 coefficient stratification as fixed effects to determine if the disease progression 443 markers explained variation in evolutionary rates. There was weak evidence that 444 disease progression markers were associated with evolutionary rate variation. The 445 Bayes Factor for midpoint CD4\%, CD4\% change rate and combined coefficient 446 stratifications ranged from 0.4 to 0.5 . Median HPM evolutionary rates did not correlate 447 with the midpoint CD4\% or CD4\% change rate (spearman correlation: $\rho=-0.3$ and 4480.7 respectively, $P>0.05)$. The median evolutionary rate estimates were similar across 449 hyperprior scale values. The median clock rate across all participants for a scale of 45010,100 and 1000 was $2.9 \times 10^{-3}$ (95\% HPD: $\left.1.6-4.9 \times 10^{-3}\right), 3.1 \times 10^{-3}(95 \%$ HPD: $1.8-$ $\left.4.9 \times 10^{-3}\right)$ and $3.1 \times 10^{-3}\left(95 \%\right.$ HPD: $\left.1.9-4.5 \times 10^{-3}\right) \mathrm{s} / \mathrm{s} / \mathrm{y}$, respectively.

\section{Estimation of site-specific selection pressures in p26}

454 Next, we used Renaissance counting procedures to quantify selection pressures in 455 p26, per participant, by estimating site-specific dN/dS ratios (44). We included 456 participants with two or more time points for this analysis $(n=9)$. Negative selection 457 predominated for all participants, with only one faster progressor showing a signature 458 of positive selection at one site (DL2051 at position five). 
medRxiv preprint doi: $h t t p s: / / d o i . o r g / 10.1101 / 2021.12 .28 .21268379$; this version posted January 7, 2022. The copyright holder for this preprint (which was not certified by peer review) is the author/funder, who has granted medRxiv a license to display the preprint in It is made available under a CC-BY-ND 4.0 International license.
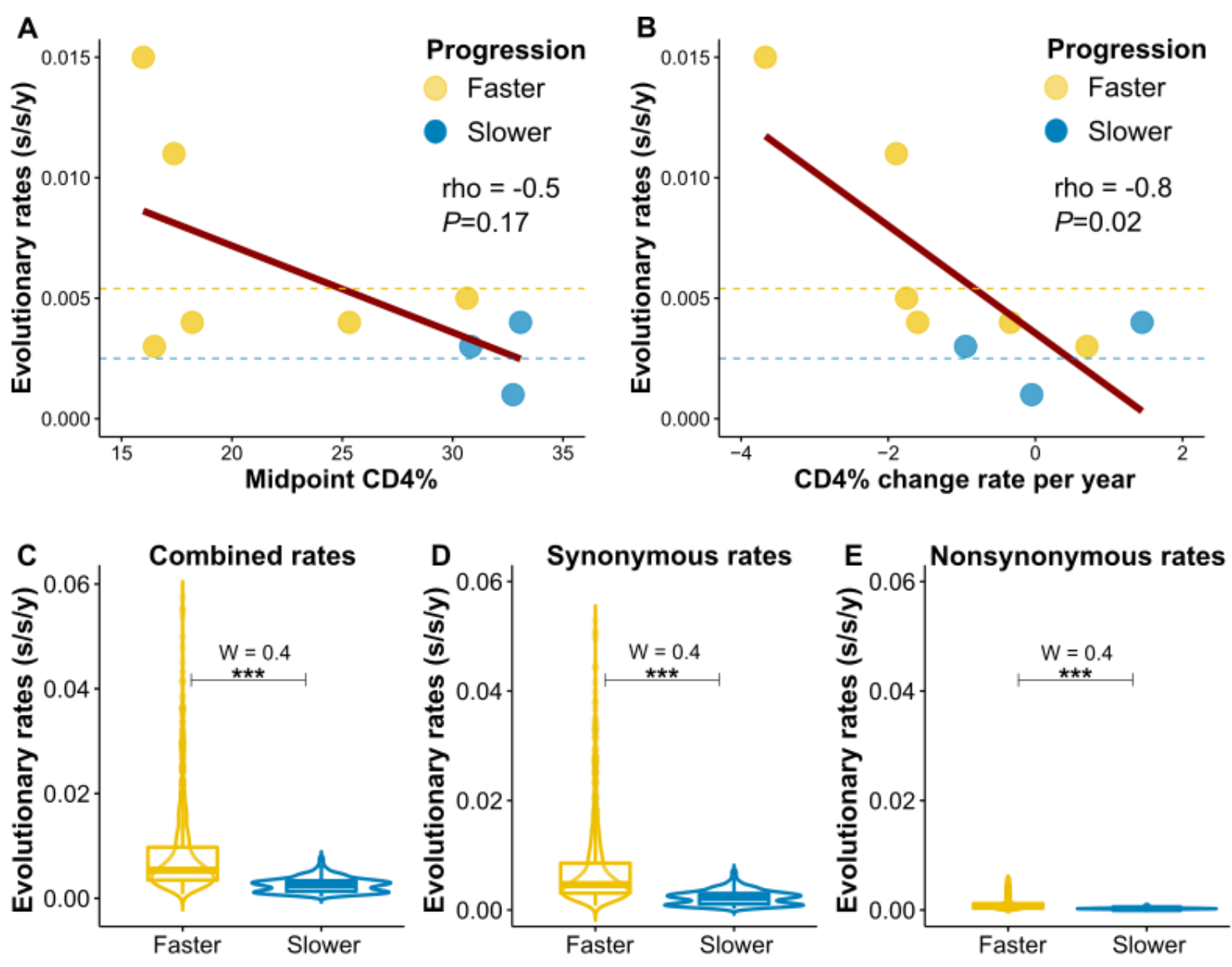

$\mathbf{F}$

G
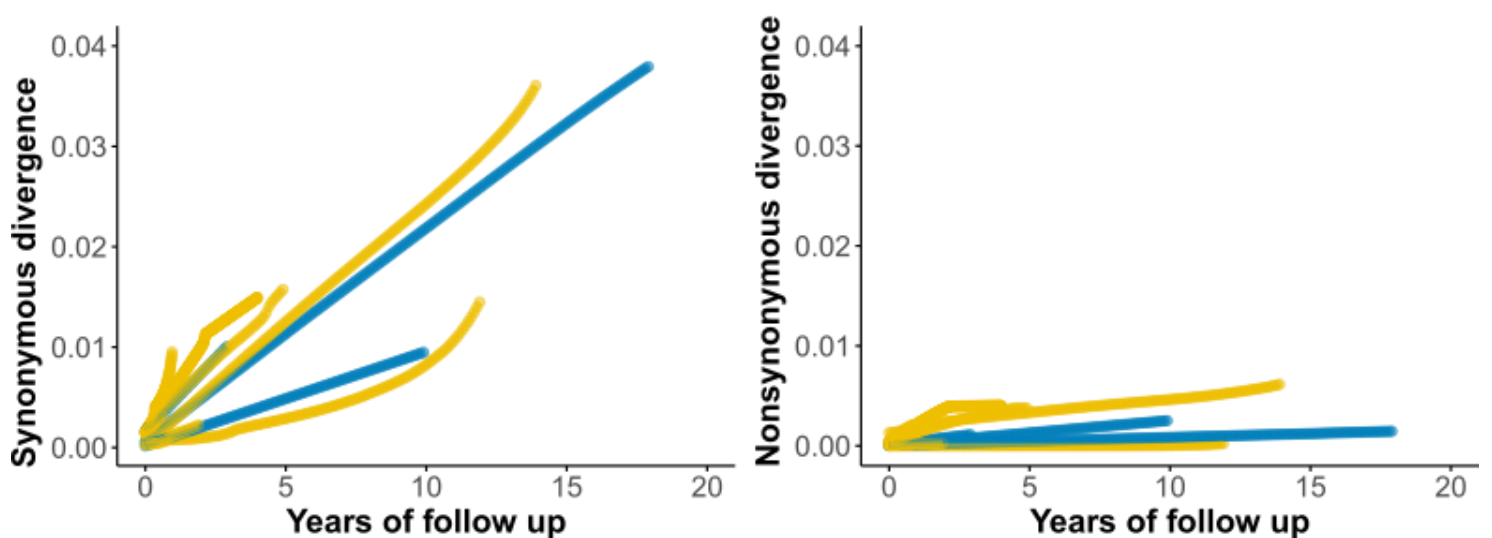

Figure 2. Evolutionary rates in relation to disease progression markers. Results are shown for the nine participants with multiple sequence time points A - B) Median relaxed clock evolutionary rates ( $y$-axis) correlated significantly with CD4\% change rate, but not CD4\% ( $x$ axes). Dashed lines show the median evolutionary rates for faster and slower progressor groups. C - E) Violin plots showing evolutionary rate distributions from 200 randomly sampled trees per patient ( $\mathrm{y}$-axis) by their respective progression group ( $\mathrm{x}$-axis). Combined, synonymous and nonsynonymous evolutionary rates were significantly higher in faster progressors (FT $P<0.001)$. F - G) Line plots of synonymous and nonsynonymous divergence (measured in substitutions per site) over time by progressor group. The accumulated divergence (y-axis) from the first analysed sample for each participant indicated by time $=0$ on the $\mathrm{x}$-axis. Faster progressors are coloured in yellow, slower progressors in blue. ${ }^{* *}=$ 
medRxiv preprint doi: https://doi.org/10.1101/2021.12.28.21268379; this version posted January 7, 2022. The copyright holder for this preprint (which was not certified by peer review) is the author/funder, who has granted medRxiv a license to display the preprint in It is made available under a CC-BY-ND 4.0 International license.

473 HIV-2 p26 amino acids signatures differ by progression status

474 All sequences were used to reconstruct the MRCA sequence at the root of the 475 maximum clade credibility tree (Figure S3). The MRCA sequence aligned well with 476 HIV-2 BEN.M30502, differing at 10 amino acid positions, and was used for amino acid 477 variant identification. In total, 61 positions among the participants' amino acid sequences differed from the MRCA sequence. After excluding private variants (found

479 in only one sequence), faster progressor amino acid sequences were more likely to 480 differ from the MRCA than slower progressor sequences (35 vs. 19 positions differed, $481 \quad \mathrm{OR}=2.0,95 \% \mathrm{Cl}=1.1-3.8, P=0.03)$

482

483 Sixty-nine unique amino acid variants were identified, and 28 of these were private 484 variants. Of the 41 remaining variants, two were major variants (present in more than $50 \%$ of all sequences) and 39 were minor variants (present in less than $50 \%$ of all sequences) Two positions on p26, 85 and 96, in the CyPA binding loop showed

487 variation from the MRCA (Figure 3). Based on the results from the VESPA analysis, 488 the amino acid at three positions differed between faster and slower disease progressors. At positions 6, 12 and 119, in slower progressors the most common amino acids were glycine, valine, and proline, and in faster progressors the most common were alanine, isoleucine, and alanine (Figure 4). These amino acid positions

492 localised to the N-terminal domain of HIV-2 p26 (Figure 4)(52). In addition, position 6 493 and 12 are located at the p26 hexamer interface surface, while 119 is next to the CyPA 494 binding loop (52-54). Many of the variants were stable in follow-up and there was little 495 evidence of specific variants being consistently selected for - agreeing with the 496 Renaissance counting results (Figure $\mathbf{3}$ ). 
medRxiv preprint doi: https://doi.org/10.1101/2021.12.28.21268379; this version posted January 7, 2022. The copyright holder for this preprint (which was not certified by peer review) is the author/funder, who has granted medRxiv a license to display the preprint in perpetuity.

It is made available under a CC-BY-ND 4.0 International license.
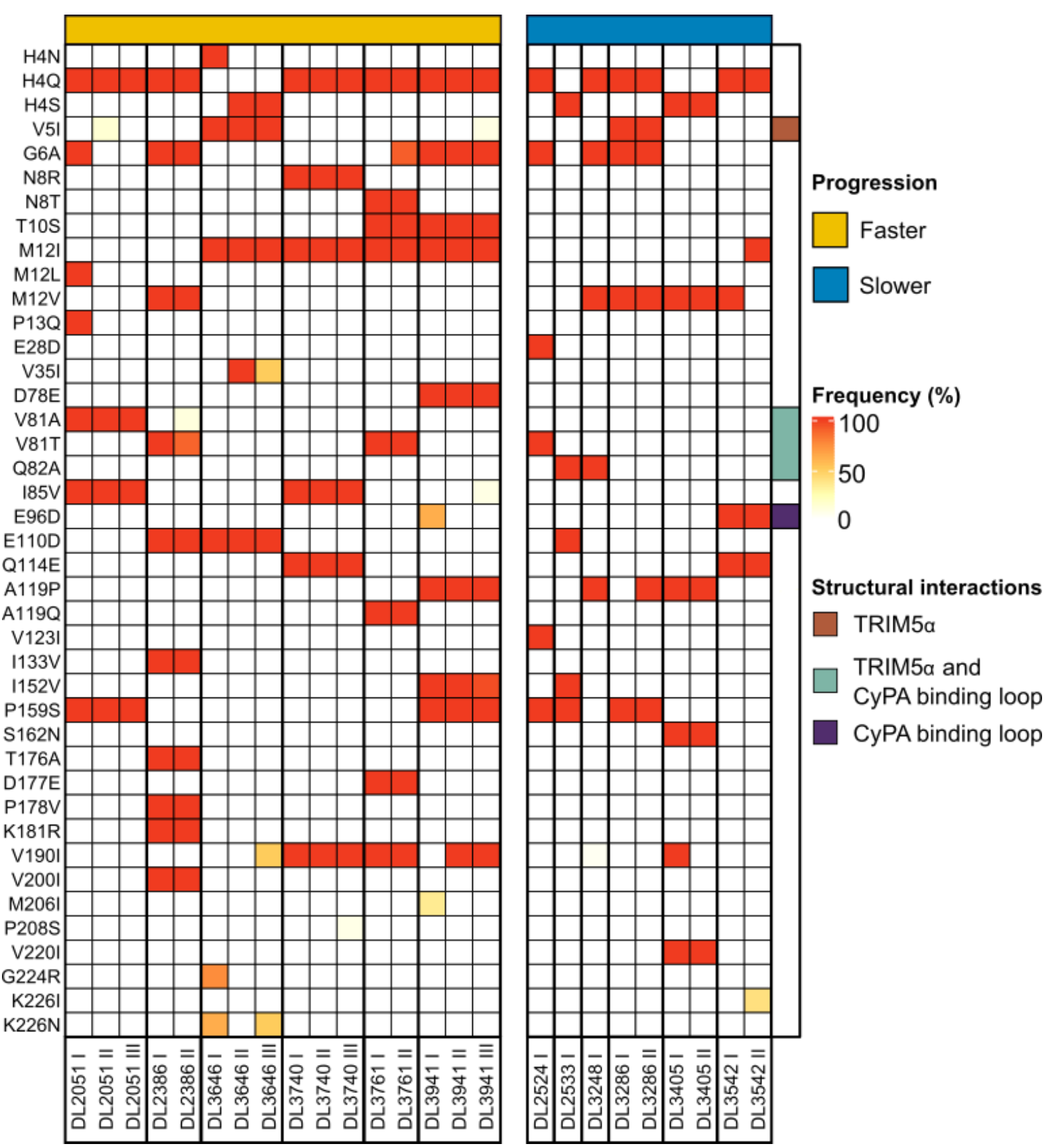

Figure 3. Heatmap of HIV-2 p26 amino acid variant frequencies over time. The y-axis shows the amino acid variants' frequencies, with the MRCA amino acid sequence used as a reference for selected positions. Each column is a participant-specific time point. Participants with their respective time points (I - III) are shown on the $\mathrm{x}$-axis, split by progression status. Variant frequencies are shown as a percentage of the sequenced quasispecies, with the scale on the right. Progressor groups are annotated on the top $\mathrm{x}$-axis, yellow = faster progressors, blue $=$ slower progressors. p26 amino acids which directly bind to TRIM5 $\alpha$ and CyPA are indicated as well. 
medRxiv preprint doi: $h t t p s: / / d o i . o r g / 10.1101 / 2021.12 .28 .21268379$; this version posted January 7, 2022. The copyright holder for this preprint (which was not certified by peer review) is the author/funder, who has granted medRxiv a license to display the preprint in It is made available under a CC-BY-ND 4.0 International license .
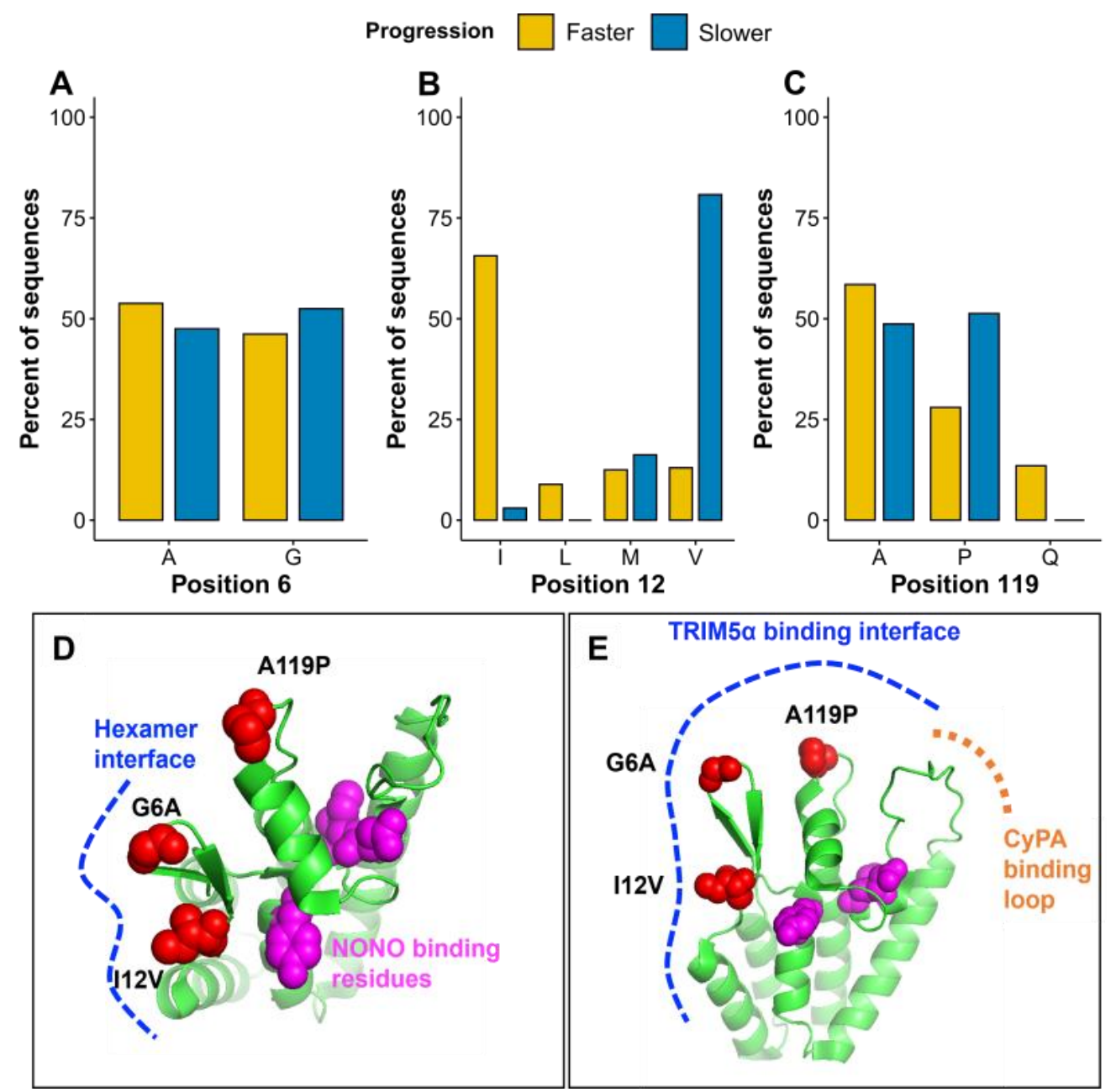

508 Figure 4. Amino acid sequence diversity in HIV-2 p26 by progression status. A - C) The amino acid signature was different at three positions on p26 between faster and slower progressor alignments. The $y$-axis shows the percentage of sequences from the pooled sequences per progressor group. D) This model of HIV-2 p26 NTD (PDB ID: 2WLV) with space-filling models of the three residues (red) and those involved in NONO binding (magenta). The p26 hexamer interface is shown in blue. E) The same model as in panel D, but at a different angle, indicating the larger TRIM5 $\alpha$ binding interface (blue) and CyPA binding loop (orange).

\section{Amino acid residues at p26 positions 6, 12 and 119 in the Caio cohort}

To test whether the association between p26 amino acids and disease progression

518 held in a larger cohort, we assessed their association with CD4\% and HIV-2 viral loads

519 in the Caio cohort. The proportions of amino acids at positions 6, 12 and 119 in the

520 Caio cohort were similar to those in the Police cohort (Figure S5). p26 Amino acids

521 were not associated with CD4\% in the Caio cohort, and only proline at position 119

522 was associated with lower HIV-2 plasma viral loads (Figure S5). 
medRxiv preprint doi: https://doi.org/10.1101/2021.12.28.21268379; this version posted January 7, 2022. The copyright holder for this preprint (which was not certified by peer review) is the author/funder, who has granted medRxiv a license to display the preprint in It is made available under a CC-BY-ND 4.0 International license.

\section{Discussion}

524 Synonymous and nonsynonymous evolutionary rates in p26 were significantly higher 525 in faster disease progressors and correlated negatively with CD4\% change rates. This broadly agrees with a previous study of partial HIV-2 env from the same cohort which found that faster progressors (determined via the midpoint CD4\% or the combined coefficient stratification) had higher evolutionary rates (15). In HIV-1, p24 synonymous and nonsynonymous evolutionary rates have shown comparable estimates

$530\left(1.6 \pm 1.3 \times 10^{-3} \mathrm{~s} / \mathrm{s} / \mathrm{y}\right.$ and $2.5 \pm 4.8 \times 10^{-3} \mathrm{~s} / \mathrm{s} / \mathrm{y}$, respectively) (45). In our analysis, HIV-2 nonsynonymous evolutionary rates are an order of magnitude lower than the synonymous rates. Findings from a study of interhost evolution of HIV-2 p26, showed little evidence of positive selection in HIV-2 p26 evolution (49). This is surprising as strong Gag-specific CTL responses are common in HIV-2 long-term non-progressors (55). It is possible that the HIV-2 capsid is not able to readily adapt to host immune responses without the virus losing ability to successfully replicate - though this would need further experimental confirmation. If true - this may explain why protection from

538 Gag-specific CTL responses is sustained in HIV-2 long-term non-progressors. This adds further evidence that immune escape, and subsequent positive selection, in the HIV-2 capsid are not associated with disease progression.

542 Hierarchical phylogenetic model estimates had narrower 95\% HPD intervals than the

543 individual relaxed clock models, which is an expected effect of using HPM (56).

544 Besides the larger HPD intervals in the non-HPM estimates, we had good agreement 545 in results between relaxed clock models and the HPM. In addition, hyperprior scales 546 did not significantly affect evolutionary rate estimates, which suggests that our 547 estimates reflected the sequence data and not model parameters' priors. The 
medRxiv preprint doi: https://doi.org/10.1101/2021.12.28.21268379; this version posted January 7, 2022. The copyright holder for this preprint (which was not certified by peer review) is the author/funder, who has granted medRxiv a license to display the preprint in

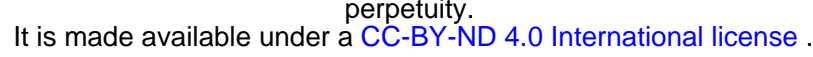

preponderance of synonymous substitutions as the main mode of evolution in HIV-2 p26 suggests that a process which is common to virus replication (either replicative capacity, generation time, or immune activation) are driving both intrahost evolution and disease progression $(11,14,57)$.

Amino acid variation from the MRCA sequence was greater in faster compared with slower progressors. Pairwise diversity and nonsynonymous divergence were also significantly higher in faster progressors. With a sustained higher nonsynonymous evolutionary rate, we would expect a greater accumulation of amino acid diversity in faster progressors compared to slower progressors. Sequence diversity correlates positively with advancing disease progression in HIV-1, and our results suggest a similar finding for HIV-2 (58).

Inferred sites on HIV-2 p26 with structural/functional motifs which have previously been linked to the HIV-1 capsid nucleotide pore, nuclear import of the capsid and NONO binding were completely conserved across all sequences (18-21). This is in line with the conserved nature of retrovirus capsids $(21,22,59)$. At three sites on p26 the most common amino acid differed between faster and slower progressors $-6,12$ and 119. Position 12 flanks a histidine at position 11 which forms part of the nucleotide channel on the capsid (18). The M12I substitution characterised faster progressor sequences, while slower progressors' most common residue was valine. At position 119 slower progressors often had a proline and faster progressors an alanine. P119 has been associated with lower viral loads and enhanced sensitivity to TRIM5a $(23,25,26)$. However, the latter finding has been contested (60). Position 119 is adjacent to the CyPA binding loop and may interact with TRIM5a. Positions 6 and 12 
medRxiv preprint doi: https://doi.org/10.1101/2021.12.28.21268379; this version posted January 7, 2022. The copyright holder for this preprint (which was not certified by peer review) is the author/funder, who has granted medRxiv a license to display the preprint in It is made available under a CC-BY-ND 4.0 International license.

573 are located close to the hexamer interface, as well as the CyPA binding loop. This

574 raises the possibility that amino acid variation at these residues can influence the

575 hexamer formation and/or TRIM5a-mediated immune activation. Further investigation

576 is needed, and in vitro experiments would be valuable in determining whether any of

577 the variants or, haplotypes thereof, affect virus replicative capacity or HIV-2-specific

578 immune responses. An alternative interpretation of the amino acid diversity near to the

579 p26 hexamer/TRIM5a interface surfaces is that this region has accumulated diversity

580 from ancestral sequences which adapted to primate hosts; and that the mutations

581 identified in this study do not change the HIV-2 capsid's function in human infection

$582(61,62)$. In support of this interpretation, we have shown that in a larger cohort, amino

583 acids at positions 6, 12 and 119 were not associated with CD4\%, and only A119P was associated with lower HIV-2 plasma viral loads.

Most p26 amino acid variants were stable over time, again indicating that negative selection was dominant in this region's evolution. We offer two explanations for this:

588 First, the capsid is limited in its adaptive capacity - though this does not explain why we observed significant differences in amino acid sequences between participants. Second, the median time from HIV-2 detection to plasma sample collection was 9.3

591 years. In p26 the primary driver of adaptive mutations are CTL responses $(63,64)$.

592 Cytotoxic lymphocyte responses drive HIV adaptation in the early stages after 593 infection, and therefore these changes may not have been captured by our sampling 594 timeframe $(65,66)$.

596 Limitations to our study include that we analysed a small sample of HIV-2 positive 597 participants $(n=12)$; however, this is a relatively large number given the logistical 
medRxiv preprint doi: https://doi.org/10.1101/2021.12.28.21268379; this version posted January 7, 2022. The copyright holder for this preprint (which was not certified by peer review) is the author/funder, who has granted medRxiv a license to display the preprint in It is made available under a CC-BY-ND 4.0 International license.

598 difficulties in obtaining HIV-2 RNA from plasma longitudinally. Within this cohort, we

599 were more likely to successfully sequence HIV-2 p26 in faster progressors which is

600 probably due to the typically higher viral loads in these participants, this also generated

601 a bias in our sample of sequences. Furthermore, all participants were men, who are

602 more likely to have faster disease progression $(67,68)$. Despite this, our results agreed

603 with pre-existing evidence that evolutionary rates correlate with disease progression

604 markers in HIV-2 infection.

605

606 Our study highlights what may be a fundamental difference in intrahost evolution

607 between HIV-1 and HIV-2, in that HIV-1 p24 is able to adapt to host immune responses

608 whereas HIV-2 p26 is more limited in this regard $(13,69)$. There are fewer

609 antiretrovirals available to treat HIV-2 than HIV-1; our results indicate that the new

610 generation of direct capsid inhibitors may be attractive options for ART in HIV-2

611 positive individuals $(70,71)$. HIV-2's limited ability to diversify the p26 amino acid

612 sequence also suggests that this may be a good target for vaccination strategies.

613 
medRxiv preprint doi: https://doi.org/10.1101/2021.12.28.21268379; this version posted January 7, 2022. The copyright holder for this preprint (which was not certified by peer review) is the author/funder, who has granted medRxiv a license to display the preprint in It is made available under a CC-BY-ND 4.0 International license.

\section{Additional information}

615 Acknowledgements

616 The listed authors and the members of the Sweden Guinea-Bissau Cohort Research

617 (SWEGUB CORE) group, including Babetida N'Buna, Antonio Biague, Ansu Biai,

618 Cidia Camara, Zacarias Jose da Silva, Joakim Esbjörnsson, Marianne Jansson, Sara

619 Karlson, Jacob Lopatko Lindman, Patrik Medstrand, Fredrik Månsson, Hans Norrgren,

620 Angelica A. Palm, Gülsen Özkaya Sahin and Sten Wilhelmson are indebted to the staff

621 of the Police Clinics and the National Public Health Laboratory (LNSP) in Bissau,

622 Guinea-Bissau. We thank Matthew Cotten for providing critical feedback on this

623 manuscript.

\section{Author contributions}

625 M.T.B., S.R.J., and J.E. conceptualized and designed the study. M.T.B., S.R.J., and 626 J.E. provided funding for the study. The SWEGUB CORE group provided samples

627 from which new sequences used in the study were generated. M.T.B. performed lab 628 work, inferential analyses and produced all figures and tables. J.N. assisted with 629 phylogenetic modelling and data analysis. A.P and S.K processed samples and 630 performed lab work. K.K and K.M performed the structural p26 modelling and 631 interpreted the results. C.O, T.D.S and A.J collected the Caio p26 sequence and 632 clinical data. M.T.B. and J.E. wrote the manuscript and all the authors reviewed, 633 edited, and approved the manuscript for submission.

634 Competing Interests - The authors declare no competing interests.

635 Funding information

636 This work was supported by funding from the Swedish Research Council (grant \#2016637 01417) and the Swedish Society for Medical Research (grant \#SA-2016). M.T.B was 638 supported by a Commonwealth Scholarship (ZACS-2016-943). 
medRxiv preprint doi: https://doi.org/10.1101/2021.12.28.21268379; this version posted January $7,2022$. The copyright holder for this preprint (which was not certified by peer review) is the author/funder, who has granted medRxiv a license to display the preprint in It is made available under a CC-BY-ND 4.0 International license .

\section{References}

640 1. Sharp PM, Hahn BH. Origins of HIV and the AIDS Pandemic. Cold Spring Harb Perspect Med. 2011 Sep;1(1):a006841.

642 2. Visseaux B, Damond F, Matheron S, Descamps D, Charpentier C. Hiv-2 molecular epidemiology. 643 Infect Genet Evol. 2016 Dec;46:233-40.

644 3. Esbjörnsson J, Månsson F, Kvist A, Silva ZJ da, Andersson S, Fenyö EM, et al. Long-term followup of HIV-2-related AIDS and mortality in Guinea-Bissau: a prospective open cohort study. The Lancet HIV. 2019 Jan 1;6(1):e25-31.

647

4. Kanki PJ, Travers KU, MBoup S, Hsieh CC, Marlink RG, Gueye-NDiaye A, et al. Slower heterosexual spread of HIV-2 than HIV-1. Lancet. 1994 Apr 16;343(8903):943-6.

5. McMichael AJ, Borrow P, Tomaras GD, Goonetilleke N, Haynes BF. The immune response during acute HIV-1 infection: clues for vaccine development. Nat Rev Immunol. 2010 Jan;10(1):11-23.

6. Theys $K$, Libin P, Pineda-Peña A-C, Nowé A, Vandamme A-M, Abecasis AB. The impact of HIV-1 within-host evolution on transmission dynamics. Current Opinion in Virology. 2018 Feb 1;28:92-101.

7. Garcia-Knight MA, Slyker J, Payne BL, Pond SLK, de Silva TI, Chohan B, et al. Viral Evolution and

8. Mild M, Gray RR, Kvist A, Lemey P, Goodenow MM, Fenyö EM, et al. High intrapatient HIV-1 evolutionary rate is associated with CCR5-to-CXCR4 coreceptor switch. Infect Genet Evol. 2013 Oct;19:369-77.

660

661

662

9. Mild M, Kvist A, Esbjörnsson J, Karlsson I, Fenyö EM, Medstrand P. Differences in molecular evolution between switch (R5 to R5X4/X4-tropic) and non-switch (R5-tropic only) HIV-1 populations during infection. Infect Genet Evol. 2010 Apr;10(3):356-64.

663

10. Williamson S. Adaptation in the env gene of HIV-1 and evolutionary theories of disease

664 progression. Mol Biol Evol. 2003 Aug;20(8):1318-25.

665

666

667

668

669

670

671

672

673

674

675

11. Lemey P, Kosakovsky Pond SL, Drummond AJ, Pybus OG, Shapiro B, Barroso H, et al. Synonymous substitution rates predict HIV disease progression as a result of underlying replication dynamics. PLoS computational biology. 2007 Feb 16;3(2):e29.

12. Bello G, Casado C, Sandonis V, Alvaro-Cifuentes T, Dos Santos CAR, García S, et al. Plasma viral load threshold for sustaining intrahost HIV type 1 evolution. AIDS Res Hum Retroviruses. 2007 Oct;23(10):1242-50.

13. Norström MM, Veras NM, Huang W, Proper MCF, Cook J, Hartogensis W, et al. Baseline CD4+ T Cell Counts Correlates with HIV-1 Synonymous Rate in HLA-B*5701 Subjects with Different Risk of Disease Progression. PLOS Computational Biology. 2014 Sep 4;10(9):e1003830.

14. Claiborne DT, Prince JL, Scully E, Macharia G, Micci L, Lawson B, et al. Replicative fitness of transmitted HIV-1 drives acute immune activation, proviral load in memory CD4+ T cells, and 
medRxiv preprint doi: https://doi.org/10.1101/2021.12.28.21268379; this version posted January 7, 2022. The copyright holder for this preprint (which was not certified by peer review) is the author/funder, who has granted medRxiv a license to display the preprint in It is made available under a CC-BY-ND 4.0 International license .

disease progression. Proceedings of the National Academy of Sciences of the United States of America. 2015 Mar 24;112(12):E1480-9.

15. Palm AA, Lemey $P$, Jansson $M$, Månsson F, Kvist A, Szojka Z, et al. Low Postseroconversion CD4+ T-cell Level Is Associated with Faster Disease Progression and Higher Viral Evolutionary Rate in HIV-2 Infection. mBio [Internet]. 2019 Feb 26 [cited 2021 Jan 7];10(1). Available from: https://mbio.asm.org/content/10/1/e01245-18

16. Sousa AE, Carneiro J, Meier-Schellersheim M, Grossman Z, Victorino RMM. CD4 T cell depletion is linked directly to immune activation in the pathogenesis of HIV-1 and HIV-2 but only indirectly to the viral load. J Immunol. 2002 Sep 15;169(6):3400-6.

17. Zhao G, Perilla JR, Yufenyuy EL, Meng X, Chen B, Ning J, et al. Mature HIV-1 capsid structure by cryo-electron microscopy and all-atom molecular dynamics. Nature. 2013 May 30;497(7451):643-6.

18. Jacques DA, McEwan WA, Hilditch L, Price AJ, Towers GJ, James LC. HIV-1 uses dynamic capsid pores to import nucleotides and fuel encapsidated DNA synthesis. Nature. 2016 Aug 10;536(7616):349-53.

19. Matreyek KA, Engelman A. The requirement for nucleoporin NUP153 during human immunodeficiency virus type 1 infection is determined by the viral capsid. Journal of virology. 2011 Aug 1;85(15):7818-27.

20. Schaller T, Ocwieja KE, Rasaiyaah J, Price AJ, Brady TL, Roth SL, et al. HIV-1 Capsid-Cyclophilin Interactions Determine Nuclear Import Pathway, Integration Targeting and Replication Efficiency. Aiken C, editor. PLoS Pathogens. 2011 Dec 8;7(12):e1002439.

21. Lahaye X, Gentili M, Silvin A, Conrad C, Picard L, Jouve M, et al. NONO Detects the Nuclear HIV Capsid to Promote cGAS-Mediated Innate Immune Activation. Cell. 2018 Oct;175(2):488501.e22.

22. Mamede JI, Damond F, Bernardo A de, Matheron S, Descamps D, Battini J-L, et al. Cyclophilins and nucleoporins are required for infection mediated by capsids from circulating HIV-2 primary isolates. Scientific reports. 2017 Mar 27;7:45214.

23. Onyango CO, Leligdowicz A, Yokoyama M, Sato H, Song H, Nakayama EE, et al. HIV-2 capsids distinguish high and low virus load patients in a West African community cohort. Vaccine. 2010 May;28:B60-7.

24. Jallow S, Leligdowicz A, Kramer HB, Onyango C, Cotten M, Wright $C$, et al. The presence of prolines in the flanking region of an immunodominant HIV-2 gag epitope influences the quality and quantity of the epitope generated. European Journal of Immunology. 2015;45(8):2232-42.

25. Song H, Nakayama EE, Yokoyama M, Sato H, Levy JA, Shioda T. A Single Amino Acid of the Human Immunodeficiency Virus Type 2 Capsid Affects Its Replication in the Presence of Cynomolgus Monkey and Human TRIM5 s. Journal of Virology. 2007 Jul 1;81(13):7280-5.

26. Miyamoto T, Yokoyama M, Kono K, Shioda T, Sato H, Nakayama EE. A Single Amino Acid of Human Immunodeficiency Virus Type 2 Capsid Protein Affects Conformation of Two External Loops and Viral Sensitivity to TRIM5 $\alpha$. Lee Y-M, editor. PLoS ONE. 2011 Jul 28;6(7):e22779. 
medRxiv preprint doi: https://doi.org/10.1101/2021.12.28.21268379; this version posted January $7,2022$. The copyright holder for this preprint (which was not certified by peer review) is the author/funder, who has granted medRxiv a license to display the preprint in It is made available under a CC-BY-ND 4.0 International license.

715

716

717

718

719

720

721

722

723

724

725

726

727

728

729

730

731

732

733

734

735

736

737

738

739

740

741

742

743

744

745

746

747

748

749

750

751

27. World Health Organization. WHO case definitions of HIV for surveillance and revised clinical staging and immunological classification of HIV-related disease in adults and children [Internet]. World Health Organization; 2007 [cited 2020 Jun 7]. Available from: https://apps.who.int/iris/handle/10665/43699

28. Esbjörnsson J, Månsson F, Kvist A, Isberg P-E, Nowroozalizadeh S, Biague AJ, et al. Inhibition of HIV-1 disease progression by contemporaneous HIV-2 infection. N Engl J Med. 2012 Jul 19;367(3):224-32.

29. van der Loeff MFS, Larke N, Kaye S, Berry N, Ariyoshi K, Alabi A, et al. Undetectable plasma viral load predicts normal survival in HIV-2-infected people in a West African village. Retrovirology. 2010 May 19;7(1):46.

30. Anglaret X, Diagbouga S, Mortier E, Meda N, Vergé-Valette V, Sylla-Koko F, et al. CD4+ Tlymphocyte counts in HIV infection: are European standards applicable to African patients? J Acquir Immune Defic Syndr Hum Retrovirol. 1997 Apr 1;14(4):361-7.

31. Norrgren H, da Silva Z, Biague A, Andersson S, Biberfeld G. Clinical progression in early and late stages of disease in a cohort of individuals infected with human immunodeficiency virus- 2 in Guinea-Bissau. Scand J Infect Dis. 2003;35(4):265-72.

32. Kearse M, Moir R, Wilson A, Stones-Havas S, Cheung M, Sturrock S, et al. Geneious Basic: an integrated and extendable desktop software platform for the organization and analysis of sequence data. Bioinformatics. 2012 Jun 15;28(12):1647-9.

33. Biomatters. Geneious Prime User Manual [Internet]. Available from: https://assets.geneious.com/documentation/geneious/GeneiousPrimeManual.pdf

34. Posada D, Crandall KA. The effect of recombination on the accuracy of phylogeny estimation. J Mol Evol. 2002 Mar;54(3):396-402.

35. Martin DP, Murrell B, Golden M, Khoosal A, Muhire B. RDP4: Detection and analysis of recombination patterns in virus genomes. Virus Evolution. 2015 Mar 1;1(1).

36. Martin D, Rybicki E. RDP: detection of recombination amongst aligned sequences. Bioinformatics. 2000 Jun;16(6):562-3.

37. Padidam M, Sawyer S, Fauquet CM. Possible emergence of new geminiviruses by frequent recombination. Virology. 1999 Dec 20;265(2):218-25.

38. Martin DP, Posada D, Crandall KA, Williamson C. A modified bootscan algorithm for automated identification of recombinant sequences and recombination breakpoints. AIDS Res Hum Retroviruses. 2005 Jan;21(1):98-102.

39. Smith JM. Analyzing the mosaic structure of genes. J Mol Evol. 1992 Feb 1;34(2):126-9.

40. Posada D, Crandall KA. Evaluation of methods for detecting recombination from DNA sequences: Computer simulations. PNAS. 2001 Nov 20;98(24):13757-62.

41. Drummond AJ, Suchard MA, Xie D, Rambaut A. Bayesian Phylogenetics with BEAUti and the BEAST 1.7. Molecular Biology and Evolution. 2012 Aug;29(8):1969-73. 
medRxiv preprint doi: https://doi.org/10.1101/2021.12.28.21268379; this version posted January $7,2022$. The copyright holder for this preprint (which was not certified by peer review) is the author/funder, who has granted medRxiv a license to display the preprint in It is made available under a CC-BY-ND 4.0 International license .

42. Ayres DL, Darling A, Zwickl DJ, Beerli P, Holder MT, Lewis PO, et al. BEAGLE: An Application Programming Interface and High-Performance Computing Library for Statistical Phylogenetics. Systematic Biology. 2012 Jan 1;61(1):170-3.

43. Rambaut A, Drummond AJ, Xie D, Baele G, Suchard MA. Posterior Summarization in Bayesian Phylogenetics Using Tracer 1.7. Susko E, editor. Systematic Biology. 2018 Sep 1;67(5):901-4.

44. Lemey P, Minin VN, Bielejec F, Kosakovsky Pond SL, Suchard MA. A counting renaissance: combining stochastic mapping and empirical Bayes to quickly detect amino acid sites under positive selection. Bioinformatics (Oxford, England). 2012 Dec 15;28(24):3248-56.

45. Raghwani J, Redd AD, Longosz AF, Wu CH, Serwadda D, Martens C, et al. Evolution of HIV-1 within untreated individuals and at the population scale in Uganda. PLoS Pathogens. $2018 \mathrm{Jul}$ $1 ; 14(7)$.

46. Iyer S, Casey E, Bouzek H, Kim M, Deng W, Larsen BB, et al. Comparison of major and minor viral SNPs identified through single template sequencing and pyrosequencing in acute HIV-1 infection. PLOS ONE. 2015 Aug 28;10(8).

47. Korber B, Myers G. Signature pattern analysis: a method for assessing viral sequence relatedness. AIDS research and human retroviruses. 1992 Sep;8(9):1549-60.

48. Schrödinger, LLC. The PyMOL Molecular Graphics System, Version 1.8. 2015.

49. de Silva TI, Leligdowicz A, Carlson J, Garcia-Knight M, Onyango C, Miller N, et al. HLA-associated polymorphisms in the HIV-2 capsid highlight key differences between HIV-1 and HIV-2 immune adaptation. AIDS (London, England). 2018 Mar 27;32(6):709-14.

50. Kassambara A. ggpubr: 'ggplot2' Based Publication Ready Plots. R Package. 2018.

51. RStudio Team (2021). RStudio: Integrated Development Environment for R [Internet]. Boston, MA: RStudio, PBC; 2021. Available from: http://www.rstudio.com/

52. Price AJ, Marzetta F, Lammers M, Ylinen LMJ, Schaller T, Wilson SJ, et al. Active site remodeling switches HIV specificity of antiretroviral TRIMCyp. Nat Struct Mol Biol. 2009 Oct;16(10):103642.

53. Yu A, Skorupka KA, Pak AJ, Ganser-Pornillos BK, Pornillos O, Voth GA. TRIM5 $\alpha$ self-assembly and compartmentalization of the HIV-1 viral capsid. Nature Communications. 2020 Mar $11 ; 11(1): 1307$.

54. Skorupka KA, Roganowicz MD, Christensen DE, Wan Y, Pornillos O, Ganser-Pornillos BK. Hierarchical assembly governs TRIM $5 \alpha$ recognition of HIV-1 and retroviral capsids. Science Advances. 2019 Nov 1;5(11):eaaw3631.

55. de Silva TI, Peng Y, Leligdowicz A, Zaidi I, Li L, Griffin H, et al. Correlates of T-cell-mediated viral control and phenotype of CD8+ T cells in HIV-2, a naturally contained human retroviral infection. Blood. 2013 May 23;121(21):4330-9.

56. Suchard MA, Kitchen CMR, Sinsheimer JS, Weiss RE. Hierarchical Phylogenetic Models for Analyzing Multipartite Sequence Data. Systematic Biology. 2003;52(5):649-64. 
medRxiv preprint doi: https://doi.org/10.1101/2021.12.28.21268379; this version posted January $7,2022$. The copyright holder for this preprint (which was not certified by peer review) is the author/funder, who has granted medRxiv a license to display the preprint in It is made available under a CC-BY-ND 4.0 International license .

57. Asowata OE, Singh A, Ngoepe A, Herbert N, Fardoos R, Reddy K, et al. Irreversible depletion of intestinal CD4+ T-cells is associated with T-cell activation during chronic HIV infection. JCl Insight. 2021 Oct 7;e146162.

58. Troyer RM, Collins KR, Abraha A, Fraundorf E, Moore DM, Krizan RW, et al. Changes in Human Immunodeficiency Virus Type 1 Fitness and Genetic Diversity during Disease Progression. Journal of Virology. $2005 \mathrm{Jul}$ 15;79(14):9006-18.

59. Rihn SJ, Wilson SJ, Loman NJ, Alim M, Bakker SE, Bhella D, et al. Extreme genetic fragility of the HIV-1 capsid. PLoS pathogens. 2013;9(6):e1003461.

60. Takeuchi JS, Perche B, Migraine J, Mercier-Delarue S, Ponscarme D, Simon F, et al. High level of susceptibility to human TRIM $5 \alpha$ conferred by HIV-2 capsid sequences. Retrovirology. 2013;10(1):50.

61. Meyerson NR, Sawyer SL. Two-stepping through time: mammals and viruses. Trends in Microbiology. 2011 Jun 1;19(6):286-94.

62. Sauter D, Kirchhoff F. Key Viral Adaptations Preceding the AIDS Pandemic. Cell Host \& Microbe. 2019 Jan 9;25(1):27-38.

63. de Silva TI, van Tienen C, Onyango C, Jabang A, Vincent T, Loeff MFS van der, et al. Population dynamics of HIV-2 in rural West Africa: comparison with HIV-1 and ongoing transmission at the heart of the epidemic. AIDS (London, England). 2013 Jan 2;27(1):125-34.

64. Leligdowicz A, Yindom L-M, Onyango C, Sarge-Njie R, Alabi A, Cotten M, et al. Robust Gagspecific $T$ cell responses characterize viremia control in HIV-2 infection. The Journal of clinical investigation. 2007 Oct 1;117(10):3067-74.

65. Ganusov V V, Goonetilleke N, Liu MKP, Ferrari G, Shaw GM, McMichael AJ, et al. Fitness costs and diversity of the cytotoxic T lymphocyte (CTL) response determine the rate of CTL escape during acute and chronic phases of HIV infection. Journal of virology. 2011 Oct;85(20):1051828.

66. Leviyang S, Ganusov V V. Broad CTL Response in Early HIV Infection Drives Multiple Concurrent CTL Escapes. PLoS computational biology. 2015 Oct;11(10):e1004492.

67. Jespersen S, Hønge BL, Esbjörnsson J, Medina C, da Silva Té D, Correira FG, et al. Differential effects of sex in a West African cohort of HIV-1, HIV-2 and HIV-1/2 dually infected patients: men are worse off. Trop Med Int Health. 2016 Feb;21(2):253-62.

68. Peterson I, Togun O, de Silva T, Oko F, Rowland-Jones S, Jaye A, et al. Mortality and immunovirological outcomes on antiretroviral therapy in HIV-1 and HIV-2-infected individuals in the Gambia. AIDS. 2011 Nov 13;25(17):2167-75.

69. Buggert $M$, Norström MM, Salemi M, Hecht FM, Karlsson AC. Functional avidity and IL2/perforin production is linked to the emergence of mutations within HLA-B*5701-restricted epitopes and HIV-1 disease progression. J Immunol. 2014 May 15;192(10):4685-96.

70. Yant SR, Mulato A, Hansen D, Tse WC, Niedziela-Majka A, Zhang JR, et al. A highly potent longacting small-molecule HIV-1 capsid inhibitor with efficacy in a humanized mouse model. Nat Med. 2019 Sep;25(9):1377-84. 
medRxiv preprint doi: https://doi.org/10.1101/2021.12.28.21268379; this version posted January 7, 2022. The copyright holder for this preprint (which was not certified by peer review) is the author/funder, who has granted medRxiv a license to display the preprint in It is made available under a CC-BY-ND 4.0 International license.

828 71. HIV-2 Infection | NIH [Internet]. [cited 2021 Apr 29]. Available from:

829 https://clinicalinfo.hiv.gov/en/guidelines/adult-and-adolescent-arv/hiv-2-infection

830 